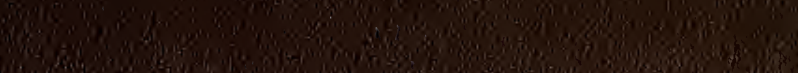

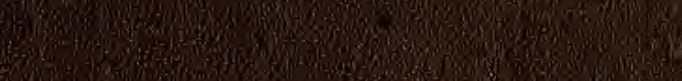
1.5.

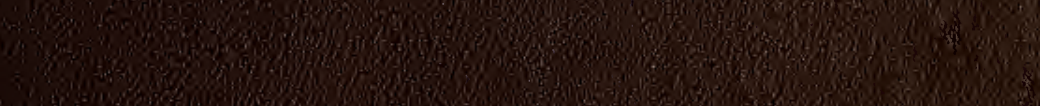

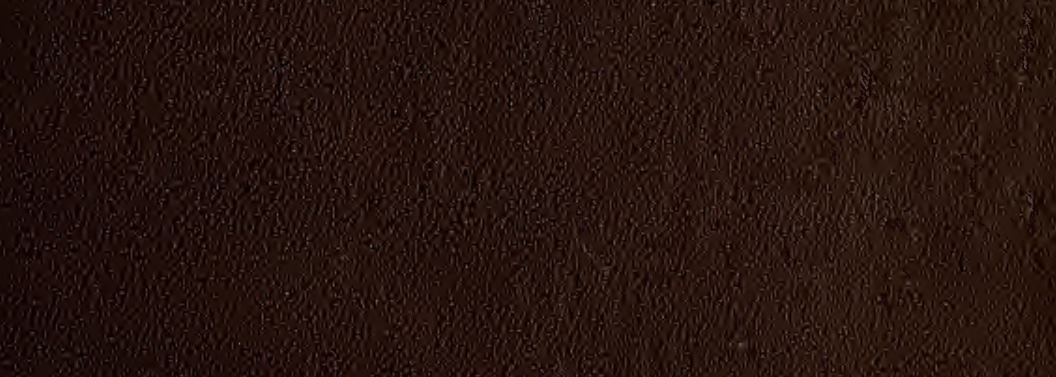

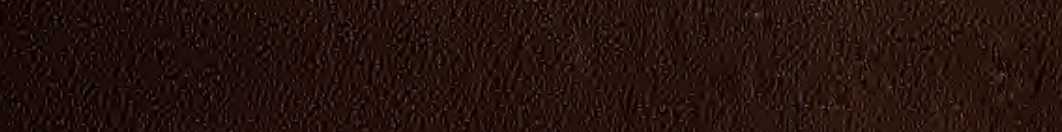
3. 


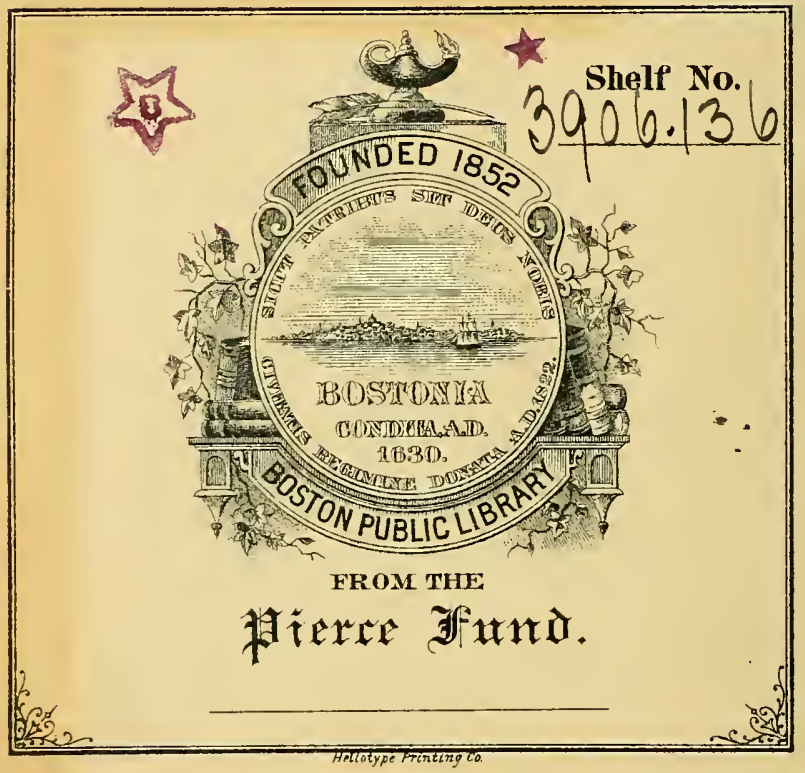




$$
\begin{aligned}
& \text { of S. Smith } \\
& \text { from of en }
\end{aligned}
$$

A

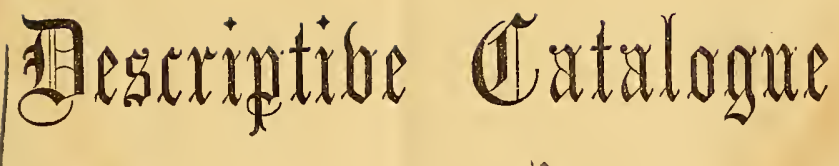 OF THE \\ BIRDS OF MASSACHUSETTS.}

By E.A. SA MUELS。

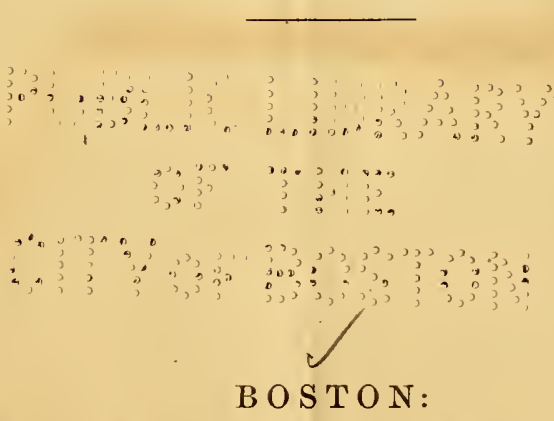

WRIGHT \& POTTER, PRINTERS, 4 SPRING LAṆE. 
(B)

Preves Opilt 10,1923

(Q)

औओ

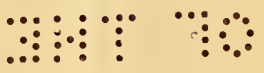

औด 


\section{BIRDS OF MASSACHUSETTS.}

[NotE. The following Catalogue has been prepared in compliance with numerous and repeated requests. It includes, so far as the observations of the author, and many other students in this department have extended, a list of all the species that have been obtained in the State, together with brief descriptive notes concerning their habits, \&c.

The classification and nomenclature are those adopted by the Smithsonian Institution. It is, probably, the best existing arrangement, and is rapidly superseding all others with American Ornithologists.]

Turkey Buzzard, Cathartes aura. Illig. Rare. 2 specimens shot in 1863.

Duck Hawk, Great-footed Hawk, Falco anatum. Bonap. Rare. Winter.

Pigeon Hawk, Bullet Hawk, Hypotriorcliis columbarius. Gr. Common. Resident. Breeds. Nests in trees; eggs 4 or 5 ; laid in May.

JER FALCON, Falco islandicus. Sabine. Rare. Winter visitor.

Sparrow Hawk, Tinnunculus sparverius. Vieillot. Common or not rare. Resident. Breeds; nests in trees; eggos 3 or 4 ; laid in May.

Gos Hawk, Astur atricapillus. Bonap. Common., Resident. Probably breeds, as specimens are often seen in summer.

Cooper's Hawk, Accipiter cooperii. Bonap. Common. Resident. Breeds; nests in high forks of trees; eggs 3 or 4 ; laid in May.

Sharp-shinned Hawk, Accipiter fuscus. Bonap. Common. Resident. Breeds; nests in trees, usually; eggs 4 or 5; laid in May.

Red-tailed Hawk, Buteo borealis. Vieill. Common. Resident. Breeds; nests in deep woods, in high forks of trees; eggs 3 or 4 ; laid in May.

Red-shouldered HaWк, Buteo lineatus. Jardine. Common. Resident. Breeds; nest in trees; eggs 3 or 4 ; laid in May.

BroAd-WINGED HAWK, Buteo pennsylvanicus. Bonap. Rare. Resident. A pair bred in Newton in 1863 ; nest in high fork; eggs 2.

Rovgh-LEGGed Hawk, Archibuteo lagopus. Gray. Rare. No instance on record of breeding here.

Black Hawk, Archibuteo sancti-johannis. Gray. Rare visitor in winter.

Marsh Hawr, Circus hudsonius. Vieillot. Common. Summer visitor. Breeds; nests in marshes, on the ground; eggs 4 to 6 ; laid early in May.

Golden Eagle, Aquila canadensis. Cassin. Rare. Not known to breed.

BALd EAgle, Haliaetus leucocephalus. Savigny. Rare. Does not breed in the State.

Fish Hawk, Osprey, Pandion carolinensis. Bon. Not rare. Summer visitor. Occasionally breeds; nests in forks of trees; eggs laid in April or May.

Great Horned Owe, Bubo virginianus. Bon. Common. Resident. Breeds; nests in hollows of trees, and in high forks of pines; eggs 2 to 4 , laid in March. 
Mottled OwL, Screech Owl, Scops asio. Bonap. Common. Resident. Nests in hollow trees; eggs 3 or 4, laid in March or April.

Long-Eared Owl, Otus wilsonianus. Lesson. Not rare. Resident. Breeds; nests in hollow trees and high pines; eggs 2 to 4, laid in March or April.

Short-Eared Owl, Brachyotus cassinii. .Brewer. Not rare. Resident in open winters. Probably breeds, as specimens are often shot in summer.

Great Gray Owl, Syrnium cinereum. Aud. Very rare, in winter.

Barred Owl, Syrnium nebulosum. Gray. Common in some districts. Resident. Probably breeds.

Sparrow OwL, Nyctale richardsonii. Bonap. Rare. Occasional resi- . dent. Not known to breed.

SAw-whet OwL, Nyctale acadica. Bon. Rare. Occasionally resident. Breeds.

SNowy OwL, Nyclea nivea. Gray. Common. Winter visitor.

Hawк OwL, Surnia ulula. Bonap. Very rare in winter.

Yellow-Billed Cuckoo, Coccygus americanus. Bonap. Common. Summer visitor. Breeds; nests in shrubs and bushes; eggs 4 or 5 ; laid in May.

Black-Billed Cuckoo, Coccygus erythrophthalmus. Bonap. Common. Summer visitor. Breeds; nests in bushes and low trees; eggs 4 or 5 ; laid in May.

Hairy Woodpecker, Picus villosus. Linn. Common. Resident. Breeds; nests in excavations in trunks and limbs of trees; eggs 4 to 6 ; laid in May.

Downy Woodpecker, Picus pubescens. Linn. Common. Resident. Breeds; nests in excavations in trees; eggs 4 to 6 ; laid in last week in April or first of May.

Black-Backed, Three-tond, Woodpecker, Picoides arcticus. Gray. Rare. Winter visitor. Not known to breed.

Banded Three-tond, Woodpecker, Picoilles hirsutus. Gray. Very rare. Winter visitor. Not known to breed.

Yellow-bellied Woodpecker, Sphyropicus varius. Baird. Not rare. Summer visitor. Breeds; nests in excavations in trees; eggs 4 to 6 ; laid in May.

BLAcK WooDcock, Pileated Woodpecker, Hylotomus pileatus. Baird. Not common. Resident. Breeds; nests in hollow trees, and in excavations made by the bird; eggs 4 to 6 ; laid in May.

Red-headed Woodpecker, Melanerpes erythrocephalus. Sw. Not common. Summer visitor. Breeds; nests in excavations in trees; eggs 4 to 6 ; laid in May or June.

Golden-WINGED WOODPECKer, Yellow-shafted Woodpecker. Colaptes auratus. Sw. Common. Summer visitor. Resident in mild winters. Breeds; nests in excavations in trees; eggs 4 to 6 ; laid in May.

Ruby-tirnoated Humming-Bird, Trochilus colubris. Linn. Common. Summer visitor. Breeds; nests in trees; eggs 2 ; laid in May or June. 
Chimner Swallow, Chaetura pelasgia. Steph. Common. Summer visitor. Breeds; nests in chimneys and hollow trees; eggs 4 to 5 ; laid in May.

Whip-Poor-tVill, Antrostomus vociferus. Bonap. Common. Summer visitor. Breeds; eggs 2 in number; laid on the ground in May or June.

Night Hawk, Chordeiles popetue. Baird. Common. Summer visitor. Breeds; eggs 2 ; laid on the bare ground or rock in May.

Belted Kingfisher, Ceryle alcyon. Boie. Common. Summer visitor. Breeds; nests in excavations in sand-banks; eggs 4 to 6 ; laid in April or May.

Krng Bird, Tyrannus carolinensis. Baird. Common. Summer visitor. Breeds; nests in trees, usually in orchards; eggs 4 to 5 ; laid in May.

Great-Crested Flycatcher, Myiarchus crinitus. Cab. Not common. Summer visitor. Breeds occasionally; nests in holes in trees and fences; eggs 4; laid in May or June.

Pewee, Phebe Bird, Sayornis fuscus. Baird. Common. Summer visitor. Breeds, often twice; nests beneath bridges, and in caves and sheds; eggs 4 to 5 ; laid in May and July.

Olive-Sided Flycatcher, Contopus borealis. Baird. Not common. Summer visitor. Breeds; nests in cedar trees; eggs 4; laid in May or June.

Wood Pewes, Contopus virens. Cab. Common. Summer visitor. Breeds; nests in trees in deep woods; eggs 4 to 5 ; laid in May or June.

Traill's Frycatcher, Empidonax traillii. Baird. Not common. Summer visitor. Breeds occasionally; nests in trees like E. minimus; eggs 4 to 5 ; laid in May or June.

Least Flycatcher, Empidonax minimus. Baird. Common. Summer visitor. Breeds, often twice; nests in trees, often in orchards; eggs 4 to 5 ; laid in May and July.

Yellow-bellied Flycatcher, Empidonax flaviventris. Baird. Rare. Summer visitor. Probably breeds.

Wood Tnuesh, Song Thrush, Turdus mustelinus. Gm. Common. Summer visitor. Breeds; nests in low trees and shrubs in deep woods; eggs 4 to 5 ; laid in May.

Herme Thrusn, Turdus pallasi. Cab. Common in spring and fall; occasionally seen in summer, and has been known to breed; nests near or on the ground; eggs 4 to 5 ; laid in May.

Wicson's Turusir, Tawny Thrush, Turdus fuscescens. Stephens. Common. Summer visitor. Breeds; nests in bushes, thickets of briers, and often on the ground; eggs 4 to 5 ; laid in May.

Olive-BaCked Turush, Turdus swainsonii. Cab. Often seen in spring and fall. Not known to breed in this State.

Gray-chened Thrush, Turdus alicice. Baird. Probably occurs, but have not seen it.

Robin, Turdus migratorius. Linn. Common. Summer visitor. Resident in mild winters. Breeds, often twice; nests in trees; eggs 4 to 5 ; laid in April or May, and July. 
Blue Brrd, Sialia sialis. Baird. Common. Summer visitor. Breeds, often twice; nests in hollow trees and martin boxes; eggs 4 to 5 ; laid in April and July.

Rubi-crowned Wrex, Regulus calendula. Licht. Common in spring, fall, and winter. Not known to breed.

Golden-Crested Wren, Regulus satrapa. Licht. Common in spring, fall, and winter. Not known to breed.

Trt LARK, Anthus ludovicianus. Lieht. Common in spring and fall.

Black-And-white Creeper, Mniotilta varia. Vieill. Common. Summer visitor. Breeds; nests on the ground, near rocks; eggs 4 to 6 ; laid in May.

Blue, Yellow-Backed Warbler, Parula americana. Bonap. Not common. Summer visitor. Breeds; nests in small limbs of trees; eggs 4; laid last of May.

Maryland Yellow-throat, Geothlypis trichas. Cab. Common. Summer visitor. Breeds; nests on the ground ; eggs 4 to 6 ; laid in May.

Mourning Warbler, Geothlypis philadelphia. Baird. Very rare. Summer visitor.

Connecticut Warbler, Oporornis agilis. Baird. Occurs rarely in spring and fall.

Yellow-breasted Chat, Icteria viridis. Bonap. Rare. Summer visitor. Breeds occasionally; nests in low bushes, near the ground; eggs 4 ; laid in June.

Worm-eating Warbler, Helmitherus vermivorus. Bonap. Not common in spring. Not known to breed.

Blue-twinged Yellow Warbler, Helminthophaga pinus. Baird. Very rare; a few specimens seen early in June.

Golden-winged Warbler, Helminthophaga chrysoptera. Baird. Very rare. Oecasionally seen in spring. Not known to breed.

Nashville Warbler, Helminthophaga ruficapilla. Baird. Common in spring. Breeds occasionally; nests in small trees; eggs 4 to 5 ; laid in May or June.

Tennesse warbler, Helninthophaga perigrina. Cab. Probably occurs in spring, rarely.

Golden-crownfed Thrush, Seiurus aurocapillus. Sw. Common. Summer visitor. Breeds; nests on the ground; eggs 4 to 6 ; laid in May or June.

Water Thrush, Seiurus noveboracensis. Nutt. Not common. Spring and fall visitor. Probably breeds, as birds are often seen in summer.

Black-throated Green Warbler, Dendroica virens. Baird. Common in spring. Breeds occasionally ; nests in pines; eggs 4 ; laid in May or June.

Blach-tiroated Blue Warbler, Dendroica canadensis. Baird. Very rare in spring.

Yellow-Rump, Dendroica coronata. Gray. Common in the migrations. Not known to breed.

Blackburinian Warbler, Dendroica blackburnice. Baird. Not common. Probably breeds. 
Bay-breasted Warblel, Dendroica castanea. Baird. Rare. Only seen in the migrations.

Pine-creaping Warbler, Dendroica pinus. Baird. Common in the migrations. Breeds occasionally; nests in pines; eggs 3 to 4 ; laid in May or June.

Chestnut-sided Warbler, Dendroica pennsylvanica. Baird. Common in spring and fall. Breeds; nests in bushes; eggs 3 to 4 ; laid in May or June.

Black Poll Warbler, Dendroica striata. Baird. Common in spring and fall. Not known to breed.

Yellow Warbler, Dendroica aestiva. Baird. Common. Summer visitor. Breeds; nests in bushes and low shrubs; eggs 4 to 5; laid in May or June.

Black-And-yellow Warbler, Dendroica maculosa. Baird. Rare. Only seen in the migrations.

Cape May Warbler, Dendroica tigrina. Baird. Rare. Not known to breed, but probably does, rarely.

Yellow Red-Poll Warbler, Dendroica palmarum. Baird. Common in the migrations. Not known to breed, but probably does, rarely.

Prairie Warbler, Dendroica discolor. Baird. Not common. Summer visitor. Occasionally breeds in Massachusetts, which probably is its northern limit.

Hooded Warbler, Myiodioctes mitratus. Aud. Very rare. Summer.

Green Black-Cap Flycatcher, Myiodioctes pusillus. Bon. Very rare in spring.

Canada Flycatcher, Myiodioctes canadensis. 'Aud. Common in the migrations. Breeds rarely; nests on the ground or in low bushes; eggs 3 to 4 ; laid in May.

Redstart, Setophaga ruticilla. Sw. Common. Summer visitor. Breeds; nests in trees, on low limbs; eggs 4; laid in May or June.

Scarlet Tanager, Pyranga rubra. Vieill. Common. Summer visitor. Breeds; nests in trees, usually oaks, in deep woods; eggs 4 to 5 ; laid in Maý or June.

Barn Swallow, Hirundo horreorum. Barton. Common. Summer visitor. Breeds; nests in eaves of buildings, and in barns and sheds; eggs 4 or 5 ; laid in May, and often July.

Cliff Swallow, Hirundo lunifrons. Say. Common. Summer visitor. Breeds; nests in eaves of buildings, \&c. ; eggs 4 or 5 ; laid in May.

White-bellied Swallow, Hirundo bicolor. Vieill. Common. Summer visitor. Breeds; nests in hollow trees and martin boxes; eggs 4 to 5; laid in May.

Bank Swallow, Cotyle riparia. Boie. Common. Summer visitor. Breeds; nests in excavations in sand-banks; eggs 4 to 5 ; laid in May.

Purple Martin, Progne purpurea. Boie. Common. Summer visitor. Breeds; nests in martin boxes, \&c. ; eggs 4 ; laid in May or June.

Wax-wing Chatterer, Bohemian Wax-wing, Ampelis garrulus. Linn. Very rare. Winter visitor. 
Cedar Bred, Cherry Bird, Ampelis cedrorum. Baird. Common. Summer visitor. Is often seen in flocks in mild winters. Breeds; nests in trees; eggs laid last of May.

Great Northern Shrme, Butcher Bird, Collyrio borealis. Baird. Common in winter. Said to breed in this State, but doubtful.

Red-eyed Flycatcher, or Vireo, Vireo olivaceus. Vieill. Common. Summer visitor. Breeds; nests in low trees; eggs 4; laid in May or June.

Warbling Frycatcher, Vireo gilvus. Bonap. Not common. Summer visitor. Breeds; nests in high poplar trees; eggs 4 ; laid last of May or first of June.

White-Eyed Vireo, Vireo noveboracensis. Bonap. Common. Summer visitor. Breeds; nests in thickets of briars and vines; eggs 3 to 4 ; laid first of June.

Blue-headed Flycatcher, Vireo solitarius. Vieill. Not common, or rare. Summer visitor. Nests in trees; eggs 4 ; laid in June.

Yellow-throated Flycatcher, Vireo flavifrons. Vieill. Common. Summer visitor. Breeds; nests in low trees; eggs 3 to 4 ; laid in June.

Mocking Brrd, Mimus polyglottus. Boie. Rare. Summer visitor; occasionally breeds; nests in bushes; eggs 4 to 5 ; laid in June.

Cat Brrd, Mirnus carolinensis. Gray. Common. Summer visitor. Breeds, often twice; nests in bushes; eggs 3 to 5 ; laid in May and July.

Brown Thrush, Harporhynchus rufus. Cab. Common. Summer visitor. Breeds, often twice; nests in bushes and small trees; eggs 4 to 5 ; laid in May and July.

Long-billed Marsh Wren, Cistothorus palustris. Cab. Not common. Summer visitor. Breeds; nests in tall grass in marshes; eggs 6 to 8 ; laid in May or June.

Short-billed Marsh, Wren, Cistothorus stellaris. Cab. Common. Summer visitor. Breeds; nests in grass in marshes; eggs 6 to 8 ; laid in May or June.

House Wres, Troglodytes aedon. Vieill. Common. Summer visitor. Breeds. Nests in hollow trees, deserted blue bird's nests, martin boxes, \&e. ; eggs 6 to 9 ; laid in May and July.

Wood Wrex, Troglodytes americanus. Aud. Rare. Spring and fall. Possibly breeds.

Winter Wrex, Troglodytes hyemalis. Vieill. Rare. Occasionally seen in fall, winter, and spring.

American Creeper, Certhia americana. Bonap. Common in spring and fall." Possibly breeds; nests in holes in trees, \&c.; eggs 6 to 8 ; laid in May.

White-belled Nutnatch, Sitia carolinensis. Gmelin. Common. Resident. Breeds; nests in holes in trees, \&e.; eggs 5; laid in April or May.

Red-berlied Nutratch, Sitta canadensis. Linn. Common in spring, summer, and fall; less common in winter. Breeds; not acquainted with nest. 
Black-CaP Trtmouse, Chickadee, Parus atricapillus. Linn. Common. Resident. Breeds; nests in holes in trees, \&c.; eggs 5 to 8, and even 10; laid in April or May.

SKY LARK, Shore Lark, Eremophila cornuta. Boie. Common in winter.

Pine Grosbeak, Pinicola canadensis. Cab. Rare.' Winter visitor.

Purple Finch, Carpodacus purpureus. Gray. Common. Resident in mild winters. Breeds; nests in pines and cedars, usually; eggs 4 to 5 ; laid in May or June.

Yellow BIRD, Goldfinch, Chrysomitris tristis. Bonap. Common summer visitor. Resident in mild winters. Breeds; nests in trees; eggs 4 to 5 ; laid in June or July.

Pine Frnch, Chrysomitris.pinus. Bonap. Not rare in winter. Has been known to breed; nests in pines; eggs 4 to 5 ; laid in April or May.

Red Crossbill, Curvirostra americana. Wils. Not rare in winter. Has been known to breed; nests in Pines; eggs 4 to 5 ; laid in February.*

White-winged Crosseirl, Curvirostra leucoptera. Wils. Not common. Winter visitor.

Lesser Red Poll, Aegiothus linaria. Cab. Common. Winter visitor.

Mealy Red Poll, Aegiothus canescens. Cab. Very rare. Winter visitor. Snow Bunting, Plectrophanes nivalis. Meyer. Common. Winter visitor.

LAPtand Longspur, Plectrophanes lapponicus. Selby. Very rare. Winter visitor.

Savannah Sparrow, Passerculus savanna. Bonap. Common. Summer visitor. Breeds twice; nests on the ground; eggs 4 to 5 ; laid in May and July.

Grass Fincr, Pooccetes gramineus. Baird. Common. Summer visitor. Breeds twice; nests on the ground; eggs 4 to 5 ; laid in May and July.

Yellow-Winged Sparrow, Coturniculus passerinus. Bonap. Not common. Breeds occasionally; nests on the ground; eggs 4 to 5 ; laid in May.

Henscon's Bunting, Coturniculus henslowi. Bonap. Very rare. Has been known to breed near. Lynn, Mass.

SharP-TAIled Finch, Ammodromus caudacutus. Sw. Not rare in sum mer. Breeds; nests in grass on or near the ground.

Sea-side Finch, Ammodromus maritimus. Sw. Common. Summer visitor. Breeds; nests in grass; eggs 4 to 5 ; laid in May.

White-crowned Sparrow, Zonotrichia leucophrys. Sw. Not common in spring and fạll.

White-throated Sparrow, Zonotrichia albicollis. Bonap. Common in spring and fall. Probably occasionally breeds.

SNow-BIRD, Junco hyematis. Sclat. Common in winter. Occasionally breeds; nests on the ground; eggs 4 to 5 ; laid in June.

Tree Sparrow, Spizella monticola. Baird. Common in spring and fall. Occasionally breeds; nests in trees; eggs 3 to 4 ; laid in May or June.

Field Sparrow, Spizella pusilla. Bonap. Common. Summer. visitor. Breeds twice; nests on the ground; eggs 4 to 5 ; laid in April, or May and July. 
Chipping Sparrow, Spizella socialis. Bonap. Common. Summer visitor. Breeds; nests in trees; eggs 4 to 5 ; laid in May and July.

Song Sparrow, Melospiza melodia. Baird. Common. Summer visitor. Breeds; nests on the ground; eggs 4 to 5 ; laid in April and July.

Swamp Sparrow, Melospiza palustris. Baird. Common. Summer visitor. Breeds; nests on the ground, in swamps; eggs 4 to 5 ; laid in May.

Fox-colored Sparrow, Passerella iliaca. Sw. Common in spring and fall.

Black-throated Bunting, Euspiza americana. Bonap. Rare. Summer visitor. Not known to breed.

Rose-breasted Grosbeak, Guiraca ludoviciana. Sw. Common. Summer visitor. Breeds; nests in low trees and shrubs, in or near swamps; eggs 4; laid in May or June.

Indigo Bird, Cyanospiza cyanea. Baird. Common. Summer visitor. Nests in bushes; eggs 4 to 5 . laid in May or June.

Ground Robin, Towhee Bunting, Pipilo erythrophthalmus. Vieill. Common. Summer visitor. Breeds; nests in low bushes and on the ground; eggs 4 to 5 ; laid in May.

Boв-olınк, Reed Bird, Dolichonyx oryzivorus. Sw. Common. Summer visitor. Breeds; nests on the ground; eggs 4 to 6 ; laid in June.

Cow Blackbird, Cow Bunting, Molothrus pecoris. Sw. Common. Summer visitor. Breeds; lays its eggs singly in nests of other birds.

Red-winged Brackbird, Agelaius phoniceus. Vieill. Common. Summer visitor. Breeds; nests in bushes and tall grass, in meadows and swamps; eggs 4 to 5 ; laid in May.

Meadow Lark, Sturnella magna. Sw. Common. Summer visitor. Breeds; nests on the ground; eggs 4 to 5 ; laid in May or June.

OrChard OrIole, Icterus spurius. Bonap. Not eommon. Summer vis-. itor. Breeds; nests in trees; eggs 4 to 5 ; laid in Juue.

Baltmore Oriole, Icterus baltimore. Daudin. Common. Summer visitor. Breeds; nests in trees, usually elms; eggs 4 to 5; laid in June.

Rusty Blackind, Scolecophagus ferrugineus. Sw. Common in spring and fall. Not known to breed.

Boat-tailed Grakle, Quiscalus major. Vieill. Rare. Summer visitor. Nests in tall grass and reeds; eggs 5 ; laid in May or June.

Crow Blackbird, Quisculus versicolor. Vieill. Common. Summer visitor. Breeds; nests in trees; eggs 4 to 6 ; laid in May.

Raven, Corvus carnivorous. Bartram. Very rare visitor.

Commox Crow, Corvus americanus. Aud. Common. Resident. Breeds; - nests in trees; eggs 3 to 5; laid in May.

Fish Crow, Corvus ossifiagus. Wilson. Very rare visitor in summer.

Bluf JAY, Cyanura cristata. Sw. Common. Resident. Breeds; nests in trees; eggs 4 to 5 ; laid in May.

Wrid Pigeon, Ectopistes migratoria. Sw. Common. Summer visitor. Oceasionally breeds; nests in trees; eggs 2; laid in April or May.

Comson Dove, Zenaidura carolinensis. Bonap. Common. Summer visitor. Breeds; nests in trees; eggs 2 ; laid in May. 
Prairie Hen, Pinnated Grouse, Cupidonia cupido. Baird. Only found on Martha's Vineyard and Naushon. Breeds; nests on ground.

Ruffed Grouse, Bonasa umbellus. Stephens. Common. Resident. Breeds; nests on ground; eggs 6 to 10 ; laid in May.

Quarl, Virginian Partridge, Ortyx virginianus, Boriap. Common. Resident. Breeds; nests on the ground; eggs 6 to 12 ; laid in May.

Great Buue Heron, Ardea herodias. Linn. Common. Summer visitor. Breeds; nests in pines and cedars ; eggs 3 ; laid in May.

Blue Heron, Florida ccerulea. Baird. Very rare. Summer visitor.

Least Bittern, Ardetta exilis. Gray. Not very common. Summer visitor. Breeds; nests on bushes, or near the ground; eggs 3 to 4 ; laid in May.

Brttern, Stake Driver, Botaurus lentiginosus. Steph. Common. Summer visitor. Breeds; nests in bushes; eggs 3 to 5 ; laid in April or May.

Green Heron, Butorides virescens. Bonap. Common. Summer visitor. Breeds; nests in bushes or trees; eggs 3 or 4 ; laid in April or May.

Night Heron, Nyctiardea gardeni. Baird. Common. Summer visitor. Breeds; nests in trees; eggs 3 to 4 ; laid in May or June.

Golden Plover, Charadrius virginicus. Borck. Common in spring and fall in the migrations. Not known to breed.

Killdeer Plover, Aegialitis vociferus. Cassin. Common in fall and spring. Occasionally breeds; nests on the ground; eggs 3 to 4; laid in April or May.

Wilson's Plover, Aegialitis wilsonius. Cassin. Common in fall and spring.

Semipalmated Plover, Aegialitis semipalmatus. Cab. Common in the migrations.

Piping Plover, Aegialitis melodus. Cab. Passes through the State in migrating.

Black-Bellied Plover, Squatarola helvetica. Cuv. Passes through the State in the migrations.

Tunnstone, Strepsilas interpres. Illig. Rare in the migrations.

Northern Phalarope, Phalaropus hyperboreus. Bonap. Rare in spring and fall.

American Woodcock, Philohela minor. Gray. Common. Summer visitor. Breeds, often twice; nests on the ground; eggs 4 to 5 ; laid in April, or May and July.

English Snipe, Gallinago wilsonii. Bonap. Common in fall and spring. Occasionally breeds; nests on the ground; eggs 4; laid in May.

Red-Breasted Snipe, Macrorhamphus griseus. Leach. Not common in the migrations.

Kмот, Tringá canutus. Linn. Rare in fall and spring.

Purple Sandpiper, Tringa maritima. Brunnich. Rare in spring and fall.

Red-backed SANDPIPER, Tringa alpina, var. americana. Cas. Not common in spring and fall.

JACK Sxipe, Tringa maculata. Vieill. Not rare in the migrations. 
Least Sandpiper, Tringa wilsonii. Nuttall. Common in spring and fall.

Sanderling, Calidris arenaria. Illig. Common in spring and fall.

Shmipalmated Sandpiper, Ereunectes petrificatus. III. Common in spring and fall.

VIllet, Symphemia semipalmata. Hartl. Common. Summer visitor. Occasionally breeds; nests on the ground; eggs 4 ; laid in April or May.

Ter.-TALe, Gambetta melanoleuca. Bonap. Not common in fall and spring.

Yellow Legs, Gambetta flavipes. Bonap. Common in spring and fall.

Solttary SAndprper, Rhyacophilus solitarius. Bonap. Rather common. Summer visitor. Occasionally breeds; nests on the ground; eggs 4; laid in May or June.

Spotted Sandpiper, Tringoides macularius. Gray. Common. Summer visitor. Breeds; nests on the ground; eggs 4 ; laid in May or June.

Field Plover, Actiturus bartramius. Bonap. Common in spring and fall. Often breeds; nests on the ground; eggs 3 to 4 ; laid in May.

Buff-Breasted Sandpiper, Tryngites rufescens. Cab. Rare.

Marbled Godwit, Limosa feloa. Ord. Rare in autumn.

Hudsonian Godwit, Limosa hudsonica. Sw. Rare in fall.

Long-Brlled Curlew, Numenius longirostris. Wils. Rare in fall.

Hudsonian Curlew, Numenius hudsonicus. Lath. Not common in fall.

Esquimaux Curlew, Numenius borealis. Latham. Not common in migration.

Crapper, RaIl. Ralius crepitans. Gm. Rare summer wanderer.

Vrrginia RaIl, Rallus virginianus. Linn. Common. Summer visitor. Breeds; nests in bogs; eggs 4 to 6 ; laid in May or June.

Commox Rall, Porzana carolina. Vieill. Common. Summer visitor. Probably breeds.

Yallow Rarl, Porzana noveboracensis. Gm. Rare. Not known to breed.

Coот, Fulica americana, Gmelin. Common. Summer visitor. Seldom breeds; nests in bogs and morasses ; eggs 4 to 6 ; laid in May or June.

Snow Goose, Anser hyperboreus. Pallas. Rare in migrations. A specimen was shot in Boston Harbor in Jnly, 1862.

Caxada Goose, Bernicla canadensis. Boie. Common in spring and fall.

Braxt, Bernicla brenta. Steph. Common in spring and fall.

Black Duck, Anas obscura. Gm. Common in fall and spring. Often seen in winter, and occasionally breeds; nests in meadows; eggs 8 to 10 ; laid in May.

Sprig-Tarl, Pin-tail, Dafila acuta. Jenyns. Not common in spring and fall.

Greex-winged Trat, Nettion carolinensis. Baird. Not very common in spring and fall.

Blue-winged Teal, Querquedula discors. Steph. Common in the migrations.

Shovkller, Spatula clypeata. Boie. Rare in spring and fall. 
Gadwall, Chaulelasmus streperus. Gray. Rare in spring and fall. BaldPate, Mareca americana. Stephens. Rare in spring and fall. Widgeon, Mareca penelope. Bonap. Not common in spring and fall.

Summer Duck, Wood Duck, Aix sponsa. Boie. Common in spring, summer, and fall. Breeds; nests in hollow trees and stubs; eggs 8 to 10 ; laid in May.

Greater Black-head Duck, Fulix marila. Baird. Very rare in spring and fall.

Littrle Black-head Duck, Fulix affinis. Baird. Very rare in spring and fall.

Red-head, Aythya americana. Bonap. Common in spring and fall.

Canvas Back, Aythya vallisneria. Bonap. Not rare in migrations.

Golden Eye, Bucephala anericana. Baird. Common in migrations.

Butter Bald, Buffle Head, Bucephala albeola. Baird. Common in migrations. fall.

Harlequin Duck, Histrionicus torquatus. Bonap. Rare in spring and

South Southerly, Old Squaw, Harelda glacialis. Leach. Common in spring, fall, and often winter.

Velvet Duck, White-wing Coot, Melanetta velvetina. Baird. Common in migrations. Often seen in winter.

Surf Duck, Butter-bill Coot, Pelionetta perspicillata. Kaup. Common in migrations. Often seen in winter.

Scoter, Oidemia americana, Swainson. Common in the spring and fall migrations.

EIDer Duck, Somateria mollissima. Leach. Common in fall, and spring, and winter.

KIng EIDer, Somateria spectabilis. IJeach. Not rare in migrations.

Ruddy Duck, Erismatura rubida. Bonap. Common in migrations. Often seen in winter.

Sheldrake, Mergus americanus. Cass. Common in spring and fall; often seen in winter.

Red-breasted Merganser, Mergus serrator. Linn. Common in spring, fall, and often winter.

Hooded Merganser, Lophodytes cucullatus. Reich. Not common in fall, winter, and spring.

Suiw, Mergellus albellus. Selby. Very rare in fall.

Gannet, Sula bassana. Briss. Common in fall, winter, and spring, on the coast.

Cormorant, Graculus dilophus. Gray. Rare in winter on the coast.

Leach's Petred, Thalassidroma leachii. Temm. Not rare off the coast.

Wilson's Petrel, Thalassidroma wilsoni. Bonap. Not common off the coast.

Mother Cary's Chicken, Thalassidroma pelagica. Bonap. Rare off the coast.

Greater Shearwater, Puffinus major. Faber. Not common off the coast. 
Sooty Shearwater, Puffinus fuliginosus. Strick. Not common off the coast.

Mank's Shearwater, Puffinus anglorum. Temm. Rare off the coast. Pomarine Skua, Stercorarius pomarinus. Temm. Rare off the coast.

Arctic Skua, Stercorarius parasiticus. Temm. Rare off the coast.

Great Black-Bached Guld, Larus marinus. Linn. Rare in winter.

Herring Gull, Larus smithsonianus. Goles. Common. Resident.

Laughing. Gull, Chroicocephalus atricilla. Linn. Not common in. winter.

Bonaparte's Gull, Chroicocephalus philadelphia. Lawrence. Not common in spring and summer.

Kittiwake Gull, Rissa tridactyla. Bonap. Not common in winter. Occasionally seen in spring.

Marsh Tern, Sterna aranea. Wils. Rare in summer.

Sooty Tern, Sterna fuliginosa. Gm. Not rare in summer.

Wilson's Tern, Sterna wilsoni. Bonap. Common in summer. Breeds; eggrs 3 ; laid on the bare rocks in May.

Arctic Tern, Sterna macroura. Naum. Not common in spring and fall. Occasionally breeds; eggs 3 ; laid on the rocks in May or June.

Roseate Tern, Sterna paradisea. Brunn. Not common in summer.

Least Tern, Sterna frenata. Gambel. Not common in summer.

Short-tailed Tern, Hydrochelidon plumbea. Wils. Rare in fall.*

Loos, Great Northern Diver, Colymbus torquatus. Brunn. Common in spring, fall and winter. Occasionally breeds.

Black-throated Diver, Colymbus arcticus. Linn. Very rare in autumn.

Red-throated Diver, Colymbus septentrionalis. Linn. Common in fall, winter and spring.

Red-Necked Grebe, Podiceps griseigena. Gray. Not rare in winter.

Crested Grebe, Podiceps cristatus. Lath. Not rare in spring, summer and fall.

Honned Grebe, Podiceps cornutus. Latham. Not rare in spring and fall.

Carolina Grebe, Podilymbus podiceps. Lawr. Common in spring and fall.

Puffin, Mormon arctica. Illiger. Not common in winter.

Black Gulllemot, Uria grylle. Latham. Not rare in winter.

Foolisi Guillenot, Uria lomvia. Brunn. Not common in winter.

Murre, Uria ringvia. Brunn. Not common in winter.

SeA Dove, Dove Kie, Mergulus alle. Vieill. Common in winter.

* This number of Gulls and Terns may probably be increased. The species included are those known to occur by the author. 


\section{DIRECTIONS FOR COLLECTING.}

About two-thirds of these species have been obtained through various collectors, and placed in the State Cabinet. It is very desirable that this collection should be as complete as possible; and collectors and others, who are in the way of obtaining specimens, are earnestly requested to forward such as they may have to spare, both of the birds, their nests and eggs. The following brief directions for collecting are given for the benefit of those who have had but little or no experience:-

Birds should be killed with very fine shot; from Nos. 9 to 12 for birds beneath the size of a pigeon, and not coarser than No. 8. for ducks and other large birds. The advantage of using fine shot is apparent, from the fact that the wounds made by them quickly close, and bleeding ceases; besides, the plumage is not marred and the skin torn, as it is when coarser shot is used. If the bird is not shot dead, it may be easily and quickly killed by compressing the sides beneath the wings firmly between the thumb and fore-finger; this immediately produces suffocation. It will be necessary to thrust into the mouth, nostrils and vent of the bird, some cotton-wool, that the plumage may not be soiled, and, wrapping it in a paper cone, it is ready for transportation.

In collecting nests and eggs, the first important point is to perfectly identify the species. In most cases, to do this, it will be necessary to obtain the parent bird; make, on a slip of paper, a memorandum of the locality where the nest is found, and whether it is built in a tree, bush, or on the ground; the date when it was secured, and the species to which it belongs. Place this memorandum in the nest with the eggs, which may be emptied of their contents in the following simple manner: make a small puncture near the end of the egg, and another on one side,-with a needle or other sharp-pointed instrument,-and on forcing the breath. into one of these holes, either through a small blow-pipe or with the mouth, the contents of the egg are easily removed. This is the simplest manner in which the operation can be done. Of course, this method is not so desirable with those persons who are familiar with the use of egg-drills and other instruments that are so necessary in making a scientific collection, but which are not always accessible to amateur collectors. With this simple preparation, the nests and eggs may be wrapped in paper and packed in a box, and forwarded; but, if they are to be sent from a distance, it is well to pack cotton-wool around the eggs in the nest, that they may not be broken in transportation. 



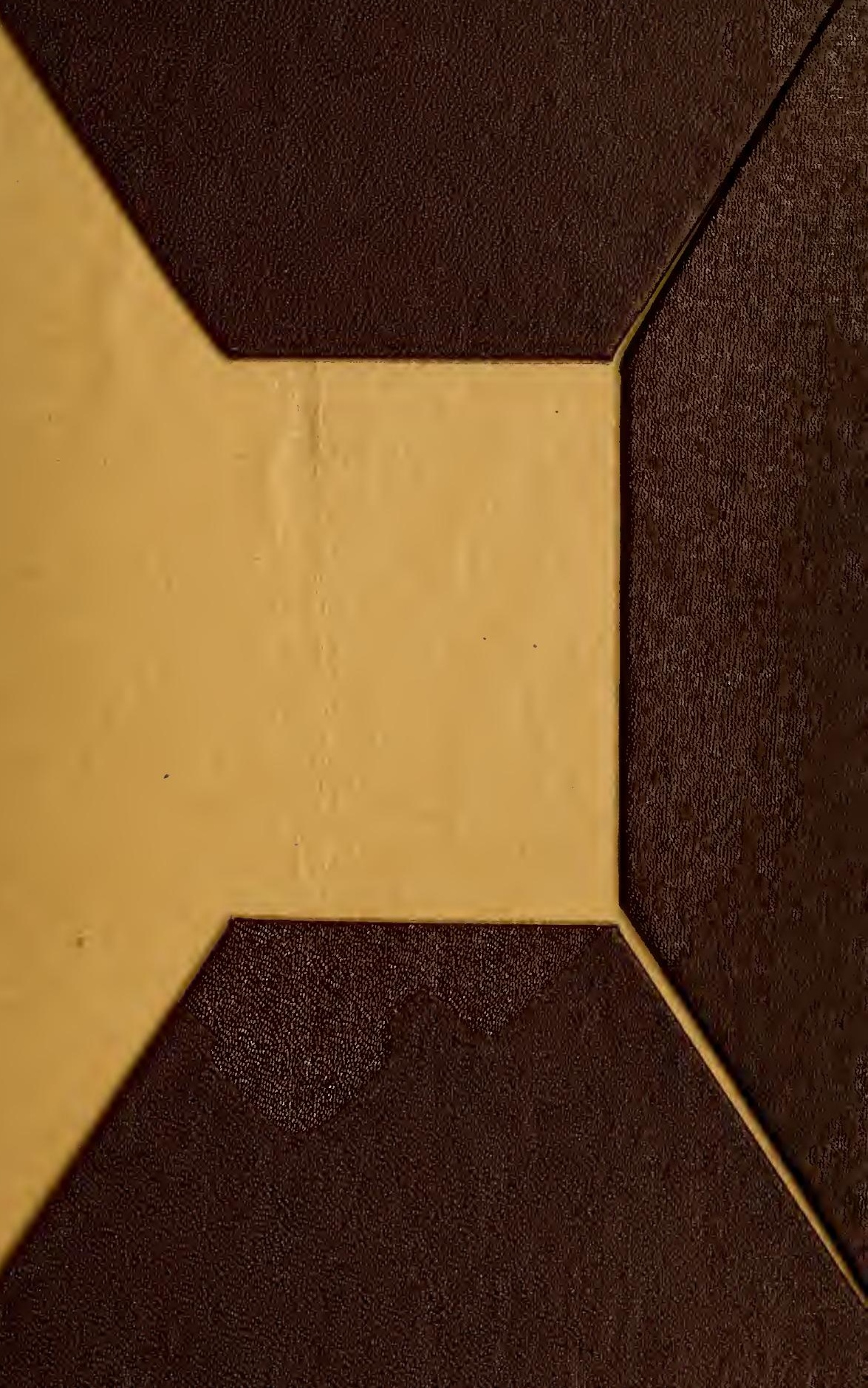


